Protestantismo em Revista é licenciada sob uma Licença Creative Commons.

http://dx.doi.org/10.22351/nepp.v43i01.2920

\title{
A identidade do evangelicalismo latino-americano: uma análise a partir da Conferência de Lausanne (1974)
}

\author{
The identity of latin americam evangelicalism: \\ an analysis from Lausanne Conference (1974)
}

Ana Rosa Cloclet da Silva*

Eduardo Vagner Santos Simões ${ }^{* *}$

\begin{abstract}
Resumo
O presente artigo analisa a formação da identidade evangelical latinoamericana a partir de seus contingentes históricos, na segunda metade do século XX. Especificamente, partindo do problema semântico que, atualmente, envolve o termo "evangélico", situa as singularidades do discurso que institui as bases teológicas e a missiologia do movimento, nos marcos de 1950-1974. Baseado no instrumental teórico de Bourdieu, acerca do conceito de "campo religioso", desenvolve uma abordagem histórica do contexto no qual configuraram-se os referenciais identitários do evangelicalismo latino-americano, culminando com a análise das preleções proferidas no Congresso de Lausanne (1974), um momento decisivo na maturidade da identidade evangelical.
\end{abstract}

Palavras-chave

Evangelicalismo. Ecumenismo. Fundamentalismo. Missão Integral. Conferência de Lausanne.

\begin{abstract}
This article analyzes the formation of Latin American evangelical identity from its historical contingents in the second half of the twentieth century. Specifically, starting from the semantic problem that nowadays involves the term "evangelical", it situates the singularities of the discourse that establishes the theological bases and the missiology of the movement,
\end{abstract}

[Texto recebido em dezembro de 2016 e aceito em junho de 2017, com base na avaliação cega por pares realizada por pareceristas ad hoc]

* Graduada em Ciências Econômicas (Universidade Estadual de Campinas). Mestra e Doutora em História (Universidade Estadual de Campinas). Pós-Doutora em História (Universidade de São Paulo). Docente do Programa de Pós-Graduação Stricto Sensu em Ciências da Religião e da Faculdade de História (PUCCampinas). Atualmente, desenvolve pesquisas na área de História das Religiões, com pesquisas focadas na articulação dos fenômenos religião e política na construção do Estado nacional brasileiro, no século XIX. E-mail: ana.silva@puc-campinas.edu.br

** Bacharel em Direito e Mestre em Ciências da Religião (PUC-Campinas). E-mail: du_simoes@hotmail.com

Protestantismo em Revista | São Leopoldo | v. 43, n. 1 | p. 20-39 | jan./jun. 2017

Disponível em: <http://periodicos.est.edu.br/index.php/nepp> 
within the framework of 1950-1974. Based on Pierre Bourdieu's concept of the "religious field", it addresses the context in which the identity references of Latin American evangelicalism were configured, culminating in the analysis of the speeches given at the Lausanne Congress (1974), a decisive moment of identity evangelical maturity.

\section{Keywords}

Evangelicalism. Ecumenism. Fundamentalism. Integral Mission. Conference of Lausanne.

\section{Introdução}

Nos últimos anos, a produção acadêmica sobre o protestantismo vem aumentando, o que se deve, em boa medida, ao fenômeno mais visível do crescimento dos pentecostais na América Latina. De tal forma que os estudos têm se dividido para abarcar protestantes de um lado - aqui o termo é usado para as igrejas históricas, ou seja, as denominações mais antigas, que chegaram ao Brasil ainda no século XIX - e pentecostais de outro. Uma breve análise das seções temáticas dedicadas ao tema, publicadas nos Anais dos últimos Congressos da Associação dos Programas de Pós-Graduação e Pesquisa em Teologia e Ciências da Religião (ANPTECRE) e da Associação Brasileira de História das Religiões (ABHR) provam essa proficuidade e atual diversidade do assunto, genericamente englobado sob o título "Protestantismo e Pentecostalismo".

Outro ponto interessante a ser notado é a predileção pelo termo evangélico nas atuais pesquisas, pouco mais de dez anos após Mendonça afirmar que o último reduto da expressão protestante era a academia, em face do peso histórico do termo. ${ }^{1}$ Designando a massa disforme e imprecisa que compõe o complexo campo religioso cristão não-católico, o termo "evangélico" parece ser a palavra mais amplamente usada em conversas informais para caracterizar tanto protestantes históricos, quanto pentecostais. Neste sentido, a linguagem acadêmica incorporou o jargão popular, implicando, como observa o metodista argentino José Míguez Bonino, o verdadeiro desgaste do termo, que passou a designar todo e qualquer cristianismo não-católico, perdendo seu poder semântico e apresentando-se como sinônimo de "protestante". ${ }^{2}$

O aspecto semântico apontado é sugestivo, pois reflete um problema que hoje parece sem solução: a definição da identidade evangélica. Afinal, quem são os evangélicos no Brasil? Diferentemente do mundo anglófono, onde o conceito evangelical tem uma importância logo percebida pelos acadêmicos, definindo um ramo específico, dentro do campo religioso protestante, no Brasil, configura-se num movimento transdenominacional.

1 MENDONÇA, Antônio G. República e pluralidade religiosa no Brasil. Revista USP, São Paulo, n. 59, set./nov. 2003, p. 144-163.

2 Bonino nitidamente usa aqui a expressão "protestante" no sentido amplo, não se restringindo apenas àquelas igrejas com confissões diretamente ligadas à Reforma do século XVI. BONINO, José Míguez. Rostos do protestantismo latino-americano. São Leopoldo: Sinodal, 2003. p. 5. 
Ou seja, o evangelicalismo não é um pensamento pertencente a uma determinada igreja, ou circunscrito por uma denominação religiosa. Pelo contrário, trata-se de um movimento que atravessa diferentes denominações e que mobiliza fiéis de diversas igrejas, em torno de uma causa comum, que abarca o evangelismo, a ação social e a militância política.

Da mesma forma, no estudo do evangelicalismo observa-se uma ausência de fronteiras institucionalizadas, no âmbito das quais se situa o movimento. Assim, para a conceituação do evangelicalismo é muito importante a noção de "auto-consciência interdenominacional", ou seja, o aspecto subjetivo do movimento. É a identificação, a empatia com certos "líderes, publicações ou instituições" que leva a uma adesão pessoal. Por esse motivo, Longuini Neto afirma que o movimento evangelical é um "movimento de pessoas", ao contrastá-lo com o movimento ecumênico, onde as igrejas se filiam ao Conselho Mundial de Igrejas. ${ }^{3}$

Assim, faz parte da identidade evangélica - ou evangelical - o sentimento de pertença a algo que transcende as barreiras denominacionais. Como afirma George Marsden, tal movimento "não se refere apenas a um grupo de cristãos que por acaso acreditam nas mesmas doutrinas; pode também significar uma auto-consciência interdenominacional, com líderes, publicações, e instituições com as quais pessoas de muitos subgrupos se identificam. ${ }^{4}$

Diante desse enorme "problema semântico", criou-se no Brasil, pelos idos da década de 1970, o neologismo - ou anglicismo - "evangelical", para designar aqueles evangélicos que identificavam-se com o pacto de Lausanne e a Teologia da Missão Integral. ${ }^{5}$ Portanto, todo evangelical é um evangélico, embora a recíproca nem sempre seja verdadeira, levando o termo a identificar "um grupo de cristãos comprometidos com um certo movimento, uma certa postura, com uma certa maneira de crer e viver a fé cristã" ${ }^{6}$ Mesmo que o neologismo restrinja-se ao cenário brasileiro e nunca tenha se popularizado entre os crentes, ainda é usado no ambiente acadêmico para fazer tal diferenciação, necessária a quem deseja um mínimo de rigor conceitual, sendo este um esforço ainda mais recente.

Para os objetivos da discussão aqui proposta, vale salientar que, a despeito do aspecto transdenominacional e pouco institucionalizado do evangelicalismo, as décadas de 1960 e 1970 se revelam de fundamental importância para a sua construção identitária. Foi então que seus representantes, leigos e teólogos, reunidos em diversos Congressos Continentais, formularam os conceitos da Teologia da Missão Integral (TMI), contemplada e popularizada pelo Pacto de Lausanne (1974), marco referencial do movimento, quando, a

3 LONGUINI NETO, Luiz. O novo rosto da missão. Viçosa: Ultimato, 2002. p. 11.

4 MARSDEN, George. Understanding Fundamentalism and Evangelicalism. Grand Rapids: Wm. B. Eerdmans Publishing Co.,1991. p. 5. (Tradução própria).

5 RODRIGUES, Ricardo Gondim. Sem perder a alma. Rio de Janeiro: MK, 2008. p. 50.

6 LONGUINI NETO, 2002, p. 22. 
partir das perspectivas anglófila e latino-americana, foram definidos os fundamentos teológicos e a ideia de integralidade da missão evangelical.

Mergulhado num contexto de profundas agitações políticas e sociais, característico das décadas em questão, a Conferência de Lausanne representou, ainda, ocasião privilegiada para as interferências recíprocas entre os campos político e religioso, na construção da identidade evangelical, sobretudo na sua vertente latino-americana. ${ }^{7}$

Dessa forma, partindo do entendimento do evangelicalismo latino-americano como mais um dentre os diversos grupos religiosos que compõem o campo religioso de disputas simbólicas, a partir da segunda metade do século XX, o presente artigo analisa as preleções dos evangelicais europeus e latino-americanos que polarizaram o debate na Conferência de Laussanne, buscando identificar o modo como estes formuladores da identidade do movimento conceberam o fenômeno religioso em foco, a partir de suas dimensões práticas - propondo formas específicas de inserção e atuação na sociedade - e do sistema de doutrinas, diferentemente apropriado em seus discursos.

Quanto a este último aspecto, é importante observar que a prática discursiva não, necessariamente, corresponde àquilo que se denomina doutrina ou teologia do grupo. Neste sentido, na análise do conteúdo discursivo do evangelicalismo, busca-se identificar as condições sociais da produção de sentido do grupo, realizadas por sujeitos históricos por meio da materialidade da linguagem, que visa produzir uma ilusão coletiva de unidade e coerência a despeito das contrariedades e diversidades dentro desse mesmo grupo. 8

\section{A configuração do campo religioso latino-americano nos anos de 1960-70}

Estabelecido o recorte histórico considerado marco na construção da identidade evangelical, é preciso compreender a natureza das disputas que configuraram o campo religioso latino-americano no período em foco, entretecidas às transformações políticas e sociais da época.

Especificamente, chama atenção o fato de que o mundo dividido entre os blocos comunista e capitalista intensificou posições e ocasionou uma maior ingerência norteamericana na América Latina, culminando na instauração de regimes de exceção em seus países. Isso acirrou a tensão entre os setores progressistas e os setores mais reacionários da sociedade, o que se refletiu também no cenário religioso. No âmbito social, as décadas

7 Tal fato justifica a pertinência de um enfoque que, inspirado pelas formulações teóricas de Pierre Bourdieu, visa entender como as relações políticas muitas vezes apresentam-se de forma "transfigurada" nas relações simbólicas, ao passo que as subversões simbólicas só conseguem afetar a ordem política quando acompanhadas de subversões também políticas. BOURDIEU, Pierre. A economia das trocas simbólicas. São Paulo: Perspectivas, 2005. p. 69.

8 ORLANDI, Eni P. Análise de Discurso. 8. ed. Campinas: Fontes, 2009. 
estudadas assistem a um crescente processo de secularização, ${ }^{9}$ com o enfraquecimento da religião predominantemente institucionalizada - o catolicismo - e o acirramento do pluralismo religioso franqueando a disputa pelo capital simbólico entre vários grupos religiosos.

Diante dessa realidade - que implica a permanente reorganização da própria religião e de suas formas de articulação com as esferas políticas, sociais e culturais ${ }^{10}$-, os grupos religiosos passaram a agir de maneiras antagônicas. Por um lado, houve um esforço de aproximação com as demais religiões e a sociedade secularizada por parte do catolicismo, num franco esforço de modernização. É nesse contexto que ocorre o aggiornamento da Igreja Católica com o Concílio do Vaticano II e a subsequente reinserção do debate sobre o pluralismo religioso. ${ }^{11}$ Por outro lado, assistiu-se ao recrudescimento e à adoção de uma postura anti-modernista, anti-ecumênica, por parte do fundamentalismo protestante, que ganha novo fôlego nessa mesma época. Internamente ao protestantismo, ensaiou-se, a princípio, uma aproximação ecumênica entre as diferentes tradições. Tal aproximação foi superada pelo que Antônio Mendonça chamou de período de repressão e isolacionismo das igrejas. ${ }^{12} \mathrm{O}$ caráter paradoxal do protestantismo - ora libertário, ora fechado em sua própria ortodoxia -, fica patente durante o período estudado.

Nesse complexo e plural campo religioso latino-americano, o evangelicalismo parece estar no meio do caminho entre fundamentalistas e ecumênicos. Por essa razão, é muitas vezes tratado como fundamentalista por alguns, especialmente autores ecumênicos. No entanto, os evangelicais rechaçam essa pecha e direcionam muitas de suas críticas aos próprios fundamentalistas, principalmente à sua missiologia conservadora, os quais, por sua vez, não demonstram qualquer interesse em definir o evangelicalismo. Portanto, é de suma importância entender as interações do evangelicalismo com as tendências em voga, de forma a identificar quais elementos foi incorporando ou rejeitando na disputa pelos bens simbólicos, na construção do campo religioso latino-americano.

A título de contextualização destas duas tendências, vale notar que, embora no continente latino-americano o ecumenismo protestante tenha-se manifestado desde as primeiras tentativas de aproximação entre "diferentes denominações protestantes",13 é somente no pós-guerra que tal tendência institucionaliza-se no âmbito internacional, com

9 Entende-se a secularização como fenômeno que "expressa o caráter paradoxal da modernidade de produzir e negar a religião, de estimular e criticar as espiritualidades". PANASIEWICZ, Roberlei. Secularização: o fim da religião?. In: ANDRADE, Paulo F. C. de; BINGEMER, Maria C. (Orgs.). Secularização: novos desafios. Rio de Janeiro: PUC-Rio, 2012. p. 9-26.

10 HERVIEU-LÉGER, Daniéle. El peregrino y el convertido: la religión en movimiento. México: Ediciones del Helénico, 2004. p. 37.

11 BINGEMER, Maria Clara L. O mistério e o mundo: paixão por Deus em tempos de descrença. Rio de Janeiro: Rocco, 2013. p. 111.

12 MENDONÇA, Antonio G. O protestantismo no Brasil e suas encruzilhadas. Revista USP, São Paulo, n. 67, set./nov. 2005, p. 61.

13 MENDONÇA, 2005, p. 55. 
a criação do Conselho Mundial de Igrejas (CMI), em 1948, na cidade de Amsterdã, Holanda. O CMI foi fruto de um longo convívio entre cristãos de diferentes tradições e denominações, "sob a inspiração do liberalismo da chamada Escola da História das Religiões" ${ }^{14}$ Sob a influência do CMI, o Setor de Responsabilidade Social da Igreja, órgão da Confederação Evangélica, realizou algumas reuniões de estudos, que culminariam na Conferência do Nordeste, realizada em Recife em 1962. É importante destacar que o Setor de Responsabilidade da Igreja atendia aos anseios revolucionários da juventude protestante intelectualizada da época, insatisfeita com o cenário político de então. ${ }^{15}$

Um ano antes da Conferência, em 1961, fora criada a Junta Latino-Americana Igreja e Sociedade, com o intuito de debater a respeito da responsabilidade social das igrejas na América Latina. No campo católico, aconteceu, em 1968, a Conferência do Episcopado LatinoAmericano, em Medelín, Colômbia, na qual se declarou a opção preferencial da igreja pelos pobres, abrindo caminho para a Teologia da Libertação.

As disputas internas ao protestantismo latino-americano acirram-se naquelas décadas. Com a aproximação entre a Junta Latino-Americana Igreja e Sociedade e a Teologia da Libertação. Com seu instrumental teórico marxista, a inclusão das igrejas russas ao CMI e as preocupações libertárias do Setor de Responsabilidade Social da Igreja, logo o ecumenismo passou a ser associado ao comunismo pelos grupos conservadores dentro das igrejas, o que deflagrou um processo de repressão no seio do protestantismo latinoamericano e ascensão de tendências fundamentalistas.

A questão do fundamentalismo, por sua vez, é ampla e complexa. Para os fins desta pesquisa, interessa situar apenas o fundamentalismo protestante, enquanto um movimento específico que surge nos EUA como uma resposta ao "modernismo", ou seja, à inserção da teologia europeia liberal nos seminários teológicos e o ensino das ciências naturais, especialmente o darwinismo, nas escolas públicas norte-americanas.

Embora tivesse o modernismo como o inimigo mais patente, em última análise, o fundamentalismo é uma resposta ao processo de secularização, que começa a ser mais fortemente percebido nos EUA no século XIX, mas que tem sua origem no racionalismo do século XVIII, podendo ser resumido na defesa da inerrância da Bíblia frente à ciência moderna, "da ortodoxia protestante a respeito da Bíblia como infalível e acima de qualquer reinterpretação que parta da ciência moderna, principalmente do evolucionismo". ${ }^{16}$

Malgrado seja um movimento que encontra suas raízes no século XIX, o fundamentalismo se institucionaliza enquanto movimento internacional no final da primeira metade do século $\mathrm{XX}$, obtendo novo fôlego no mundo secularizado e polarizado

\footnotetext{
14 MENDONÇA, 2005, p. 58.

15 MENDONÇA, 2005, p. 62.

16 MENDONÇA, 2005, p. 58.
} 
do pós-guerra. Assim como o Conselho Mundial de Igrejas (instituição ecumênica), em 1948, também em Amsterdã foi criado o Conselho Internacional de Igrejas Cristãs, de orientação fundamentalista. Seu fundador, o pastor presbiteriano norte-americano Carl McIntire, esteve algumas vezes no Brasil e sua influência é percebida na criação da Federação de Igrejas Fundamentalistas, dentro do presbiterianismo no país, derivando, nas décadas seguintes, uma postura militante anti-ecumênica.

Além das matrizes ecumênica e fundamentalista como importantes referenciais para a construção da identidade do evangelicalismo latino-americano, é ainda notório seu dinamismo histórico, registrado nos documentos dos Congressos Continentais que precederam Lausanne, iniciando-se pelas Conferências Evangélicas Latino-Americanas (CELAs), e o Congresso Latino-Americano de Evangelização, realizados nos anos de 1949, 1961 e 1969. A análise desses documentos indica a mudança de discurso dentro do protestantismo, que compreende as mudanças de fases ${ }^{17}$ que este experimentou, culminando no Congresso Internacional para Evangelização Mundial, em 1974, ponto de referência desta pesquisa.

Embora a análise desta documentação fuja ao escopo do presente artigo, vale frisar que, naqueles anos, o discurso evangelical latino-americano revelou-se especialmente dogmático, no sentido de que, as "verdades centrais" foram concebidas por seus representantes como mais importantes que a unidade entre as diferentes tradições protestantes. $^{18}$

É apenas no ano de 1969 que se pode notar uma primeira ruptura dentro do movimento, decisiva para o surgimento da identidade evangelical. Melhor explicando, a identidade e discurso evangelicais surgem graças à tensão causada pela polarização dentro do protestantismo, que opunha conservadores e progressistas. Esse é um momento de tensão tão profunda dentro do campo religioso evangélico latino-americano que gerou uma ruptura institucional no movimento. Conforme passaremos a analisar, os evangelicais latino-americanos presentes em Lausanne são fruto desta ruptura, num momento em que, ao menos quanto ao engajamento social, ainda era possível demarcar suas diferenças em relação aos evangelicals anglo-saxões.

17 Aqui, tem-se em mente a divisão dos períodos do protestantismo no Brasil proposta por Mendonça, segundo a qual o período de 1824 a 1916 seria a fase de instalação; 1916 a 1952, o projeto de unionismo; 1952 a 1962, a chegada de "teologias novas", das quais um dos principais nomes seria do missionário Richard Shaull; 1962 a 1983 corresponderia à fase de repressão e isolacionismo das igrejas. Aqui serão consideradas as duas primeiras fases como uma única fase de instalação, por se entender que não há, do ponto de vista da análise do discurso, diferenças tão significativas entre uma e outra. MENDONÇA, 2005, p. $48-67$.

18 Uma análise comparativa destes discursos permite ainda constatar que o texto final do CLADE I realizado em Bogotá, no mesmo ano do CELA III, ou seja, em 1969 - assemelha-se em alguns pontos ao texto do CELA I: em ambos, há o ímpeto conversionista, anti-catolicismo implícito ou explícito, um ecumenismo bem restrito e a ausência de qualquer engajamento social. 


\section{A construção da identidade evangelical nas preleções de Lausanne (1974)}

Conforme já mencionado, em 1974 realiza-se em Lausanne o Congresso Internacional para Evangelização Mundial, convocado por Billy Graham e a revista Christianity Today. O Congresso reuniu líderes evangélicos de vários países de todos os continentes. Sob uma retórica de unidade que se verifica no documento final do Congresso com a opção deliberada do pronome "nós", esconde-se uma disputa intensa entre os seus signatários. ${ }^{19}$

Especificamente, nas entrelinhas das principais preleções é possível notar uma cisão entre o discurso dos evangelicals anglo-saxões e os representantes do terceiro mundo. O primeiro grupo é idealmente representado por Graham e, embora seja difícil afirmar se seu discurso representava ou não a maioria dos presentes no Congresso, é certo que esse grupo era quem financiou o evento. Por sua vez, o segundo grupo é representado pelos teólogos latino-americanos como René Padilla e Samuel Escobar que, apesar de herdeiros do avivalismo e conservadorismo teológico do Evangelical Movement, em suas ênfases teológicas denunciam uma postura diferente diante da configuração e das disputas do campo religioso protestante.

Contudo, uma tônica comum a todos os discursos é a rejeição do ecumenismo e seus conceitos, assim como a construção da identidade a partir desta negação. Em outras palavras, o Congresso de Lausanne é nitidamente uma resposta às conferências anteriores realizadas pelo CMI. Alguns conceitos são discutidos, tais como missão, evangelização, igreja. Num ataque às "reformulações" teológicas dos ecumênicos, os evangélicos reafirmam uma suposta tradição, ou uma ortodoxia. No entanto, não há um consenso muito claro a respeito do que seria a "missão" da igreja. Na verdade, pode-se dizer que a formulação deste conceito é o principal ponto de disputas entre os diferentes grupos em Lausanne e as diferenças na ênfase evidenciam projetos distintos quanto ao engajamento nas circunstâncias políticas, sociais e propriamente religiosas da segunda metade do século XX.

No discurso de Graham, fica evidente o projeto missiológico dos evangelicals norteamericanos: um projeto de uma espiritualidade individual e moralizante, bem ao estilo laissez-faire dos puritanos. Qualquer mudança na sociedade passa necessariamente pela conversão e mudança individual dos conversos. E os males sociais são eminentemente de cunho religioso e moral: sendo o maior deles o declínio da religião institucional e a membresia das igrejas.

19 Estas preleções que constituem a base doumental do presente artigo estão compiladas na obra: GRAHAM, Billy et alli (Org.). A missão da igreja no mundo de hoje: as principais palestras do Congresso Internacional de Evangelização Mundial realizado em Lausanne, Suíça. São Paulo: ABU, 1984. 
Deste ponto de vista, as mudanças na configuração do campo religioso principalmente o pluralismo em voga - não são bem-vindas. A pluralidade religiosa é vista por Graham como sortilégios diabólicos.

A ausência do temor de Deus, a perda de princípios morais absolutos, a aceitação e glorificação do pecado, o fracasso no lar, o desrespeito pela autoridade, a ilegalidade, a ansiedade, o ódio e o desespero, eis os sinais de uma cultura decadente. No hemisfério ocidental, já estamos vendo sociedades traumatizadas, abaladas por guerras, escândalos, inflação, profundamente cansadas de materialismo, todas elas desencantadas com a religião sem vida. Milhares e milhares de pessoas se voltam hoje para o esotérico e o ocultismo, como o culto satânico, o controle da mente, a astrologia e outros sortilégios que o diabo utiliza para induzir os homens a se desviarem da verdade. ${ }^{20}$

O pessimismo escatológico não está embasado apenas nas novas configurações do campo religioso, mas, também, naqueles elementos que afetam o campo político e econômico. Poucos anos depois da crise dos mísseis em Cuba e no auge da crise do petróleo, a certeza da catástrofe iminente - fosse nuclear ou econômica - intensificou-se. Tal diagnóstico fica evidente quando Graham prognostica que, "por volta de 1980 (...) os países do Oriente Médio estarão de posse de quase dois terços da reserva monetária mundial", arrematando: "nós aqui, neste Congresso, temos hoje uma oportunidade sem precedentes, na medida em que o mundo se coloca à beira do Armagedom" ${ }^{21}$

Outro ponto da retórica de Graham é a afirmação de uma suposta tradição que se inicia no século passado, da qual os evangelicals seriam os legítimos herdeiros, enquanto o CMI seria uma deturpação de todo o "ardor missionário" que caracterizara a Conferência de Edimburgo. É como se os evangelicals estivessem disputando com os ecumênicos pelo passado fundante, pelo pedigree missiológico. Graham afirma: "este Congresso é o elo mais recente de toda uma longa cadeia de conferências evangelísticas iniciada no século passado que foi na expressão de Latourette, 'o grande século da expansão missionária'". 22 Para reforçar esse ponto, faz-se uma caricatura extremamente simplista do Movimento Ecumênico (ME). Ao tentar responder porque o ME, supostamente, perdeu seu “ardor missionário", Graham afirma:

Os encontros missionários de âmbito mundial que vieram depois, realizados em Jerusalém, Tambaram, Cidade do México e Bangkok, atraíram não só evangelistas e missionários, mas também grupos cada vez mais numerosos de líderes eclesiásticos eminentes que compareceram na

20 GRAHAM, B. Por que Lausanne. In: GRAHAM, Billy et alli (Org.). A missão da igreja no mundo de hoje: as principais palestras do Congresso Internacional de Evangelização Mundial realizado em Lausanne, Suíça. São Paulo: ABU, 1984. p. 14.

21 GRAHAM, 1984, p. 15.

22 GRAHAM, 1984, p. 15. 
condição de clérigos, não como evangelistas ou missionários (...). A maioria dos que tinham ficado em casa era muito mais orientada do ponto de vista evangélico e teológico. De maneira que o foco de atenção deslocou-se gradualmente da evangelização para a ação político-social. Por fim, traçaram-se diretrizes que apelavam quase integralmente para a obra de humanização, ou seja, a reconciliação do homem com o homem, e não deste com Deus. ${ }^{23}$

Assim, o carismático pastor norte-americano atribui décadas de debates e evolução do conceito de missão a uma suposta "falha de representação" nas conferências missionárias. Além disso, indiretamente atribui a "perda de ardor missionário" às igrejas do terceiro mundo, por trazerem questionamentos que ensejaram repostas controversas e perniciosas.

E qual seria a resposta dos evangelicals aos questionamentos vindos do terceiro mundo, ou a resposta "mais orientada do ponto de vista evangélico e teológico", segundo o próprio Graham? Em outras palavras, o que pensava Graham sobre o engajamento das igrejas com questões sociais? A esse respeito, chega a afirmar em determinado momento de sua preleção que "na verdade, nossa tarefa não é essa". ${ }^{24}$ Sem chegar ao radicalismo de alguns fundamentalistas que condenavam qualquer tipo de engajamento social, é nítido que, para ele, a serventia da ação social reside na "credibilidade do testemunho" missionário, ou seja, é um meio para conquistar mais prosélitos. No entanto, qualquer mudança das estruturas injustas seria apenas um corolário dos "corações convertidos", 25 expressão que indica sua concepção restrita de evangelização que, segundo ele, "pode significar tão somente a proclamação de Jesus Cristo, na convicção de que o Espírito Santo usa as Escrituras para convencer as pessoas a se tornarem discípulos de Cristo e membros de sua Igreja".26

O pragmatismo do grupo de Graham também está presente no modelo de evangelização adotado. O Comitê de Planejamento do Congresso incumbiu a Escola de Missões do Seminário Teológico de Fuller da tarefa de levantar dados para o evento. A escola de Fuller, entre outras coisas, pode ser reconhecida pela sua ênfase no crescimento e implantação de igrejas e acentuada preocupação transcultural. Tudo isso, num pragmatismo bem à moda do empreendedorismo norte-americano, permitindo-nos concluir que o discurso de Graham é também um projeto de poder.

Outro importante líder evangélico a discursar é o inglês John Stott, ministro da Igreja Anglicana e o maior expoente da ala evangélica desta mesma instituição. $O$ tom de Stott é mais moderado: não há o mesmo pessimismo e apocalipsismo presente no discurso de Graham. Provavelmente, essa moderação se deva ao fato de Stott ser europeu e,

23 GRAHAM, 1984, p. 18.

24 GRAHAM, 1984, p. 22.

25 GRAHAM, 1984, p. 24.

26 GRAHAM, 1984, p. 25 
diferentemente de seu colega norte-americano - que era formado num instituto bíblico - ter obtido seus estudos em teologia no ambiente liberal da Universidade de Cambridge. Ilações à parte, o fato é que aqui há uma diferença perceptível entre o discurso evangélico norte-americano e europeu. A despeito da não rara hostilidade entre evangélicos e ecumênicos, Stott adota uma postura, ainda que exclusivista, quase conciliatória. Afirma o pastor anglicano:

Sabemos todos nós que, nos anos mais recentes, sobretudo no período que vai de Uppsala a Bangkok, as relações ecumênico-evangélicas recrudesceram muito, a ponto de virarem confrontação, ou algo parecido. Não quero agravar a situação. Notem, contudo, por favor: acredito que parte do pensamento ecumênico labora em equívoco, mas, francamente, também acho que uma parte das formulações evangélicas incide em erro. ${ }^{27}$

Contudo, embora Stott chegue a citar e até a concordar em partes com textos produzidos pelo CMI - como o relatório de Uppsala - coube a ele a tarefa de elaborar definições teológicas para tópicos controversos, tais como missão, evangelização, etc., estabelecendo limites dogmáticos além dos quais os participantes do Congresso não deveriam se aventurar durante o encontro. Assim, expõe uma cristologia, soteriologia e eclesiologia conservadoras. Sua concepção de salvação vai além do conversionismo fundamentalista, mas revela-se crítica das novas formulações ecumênicas:

Humanização, desenvolvimento, integridade, libertação, justiça: digamos sem demora que todos esses alvos não somente são desejáveis, mas que nós, os cristãos, deveríamos persegui-los ativamente, e que os evangélicos, em particular, incorremos com frequência no erro de fazermos nossas opções sem consideração de tais responsabilidades. (...) Nada disso, porém, corresponde à "salvação" que Deus oferece ao mundo em e através de Cristo. Podemos incluir essas coisas no plano da "missão divina", na medida em que pessoas cristãs abracem essas carreiras. Mas chamar a libertação sócio-econômica de "salvação" é incorrer em rude erro teológico. ${ }^{28}$

Apesar do tom sempre ponderado de Stott, a ideia subjacente, mais uma vez, é de que as questões socioeconômicas ficam circunscritas ao âmbito individual de atuação dos cristãos em suas respectivas profissões. Portanto, por mais que não o diga expressamente, qualquer projeto de mudança estrutural da sociedade poderia ser considerado uma perda do foco missionário. A atuação do cristão na sociedade é desejável mais apenas num âmbito privado. Não há um projeto eclesiológico que gere utopias de uma sociedade diferente.

27 STOTT, J. Bases bíblicas da evangelização. In: GRAHAM, Billy et alli (Org.). A missão da igreja no mundo de hoje: as principais palestras do Congresso Internacional de Evangelização Mundial realizado em Lausanne, Suíça. São Paulo: ABU, 1984. p. 34.

28 STOTT, 1984, p. 47. 
Outros destacados representantes do grupo anglo-saxão são Michael Green, Howard Snyder e Francis Schaeffer. Cada um com diferentes ênfases e incumbidos de diferentes temas - os quais não cabe analisar no escopo do presente artigo -, suas preleções confirmam o quanto os evangélicos anglo-saxões constituíam uma voz pouco harmônica em Lausanne. ${ }^{29}$ Os principais preletores e os grupos por eles representados variam num espectro que vai dos mais radicais aos mais moderados herdeiros do fundamentalismo reavivado pelo Evangelical Movement da segunda metade do século XX. No entanto, há uma semelhança: o lugar secundário conferido à questão da responsabilidade social. Aqueles que não a ignoram tratam a responsabilidade social como tópico de menor importância. No máximo, demonstram um interesse pragmático pelo assunto. Essa é a diferença fundamental em relação ao discurso dos evangélicos latino-americanos, conforme passaremos a analisar.

Apesar de, teologicamente, as preleções de Lausanne seguirem uma mesma base o conservadorismo teológico evangélico -, há uma diferença de ênfase significativa que informa os discursos. Enquanto os anglo-saxões dão maior atenção à conversão, à necessidade de enunciação dos conteúdos do evangelho, à qualidade desses conteúdos, os latino-americanos apresentam uma linguagem mais cosmológica. Assim, enquanto os primeiros preferem falar em salvação, os latino-americanos preferem falar em reconciliação, restauração cósmica e, o que é ainda mais importante, dão atenção ao que se pode chamar de "dimensão estrutural do pecado": ou seja, a corrupção do gênero humano não estaria apenas no indivíduo, mas também nas estruturas sociais e econômicas.

Os latino-americanos, no caso, são representados pelo equatoriano René Padilla e o peruano Samuel Escobar. Não que fossem os únicos presentes no evento, nem os únicos teólogos conhecidos do continente. No entanto, suas preleções foram bem provocativas, tornando-os bons representantes do que seria o evangelicalismo latino-americano dos anos seguintes. Ambos formaram-se na tradição do protestantismo de missão, ou conversão; envolveram-se com a missão estudantil, CIEE; obtiveram formação teológica em países anglófonos; 30 estiveram no primeiro Congresso Latino-Americano de Evangelização, em 1969, e fundaram juntos a FTL, em 1970.

Padilla, em sua preleção, não abandona a soteriologia conservadora e faz acirradas críticas ao universalismo, argumentando que:

Obviamente, a salvação de Deus em Cristo Jesus é universal em seu escopo. Mas a universalidade do Evangelho não deve ser confundida com

29 Os títulos das preleções destes evangelicais, denunciam a diversidade de temas tratados. Respectivamente: "Evangelização na Igreja Primitiva (comentário)", p. 75-84; "A Igreja como Agente de Deus na Evangelização (tese)", p. 87-118; “Forma e Liberdade na Igreja (Tese”, p. 207-224).

30 Escobar doutorou-se em História da Igreja pela Universidade de Boston, EUA, e Padilla em Exegese do Novo Testamento pela Universidade de Manchester, RU. 
universalismo dos teólogos contemporâneos que sustentam, tomando como base a obra de Cristo, terem todos os homens recebido a vida eterna, não importando sua posição diante de Cristo. ${ }^{31}$

No entanto, fazendo uso deliberado da palavra "cósmica", propõe o que concebe como uma visão mais holística:

O Evangelho é uma mensagem pessoal, que revela a presença de um Deus que chama cada um dos seus pelo nome. Mas é também uma mensagem cósmica, ao revelar a presença de um Deus em cujo propósito se inclui o mundo inteiro. Esse Evangelho não se dirige ao indivíduo per se, mas ao indivíduo como membro da velha humanidade em Adão, marcada pelo pecado e pela morte, e a quem Deus convida para integrar-se na nova humanidade em Cristo, marcada pela retidão e pela vida eterna. ${ }^{32}$

Nesta perspectiva, os dois arquétipos que Padilla ataca são o "Cristianismo Secular" e o "Cristianismo Etnocêntrico". Nessa quase ambiguidade, o teólogo ainda se coloca entre o "conversionismo" e o que chamou de "escatologias seculares", em especial, o marxismo, defendendo que:

(...) a única evangelização verdadeira é a que se dirige para o objetivo final da "restauração de todas as coisas" em Jesus Cristo, prometida pelos profetas e proclamada pelos apóstolos (At 3.21). A escatologia centrada na salvação futura da alma acaba sendo demasiado limitada em face das escatologias seculares de nosso tempo, a mais importante das quais - a marxista - espera instaurar a sociedade ideal e a criação de um novo homem. ${ }^{33}$

Apesar disso, emprega conceitos do materialismo ao advogar a respeito da "dimensão estrutural do pecado", afirmando que este "é um problema social e até mesmo cósmico, e não apenas individual", de tal forma que "a evangelização não se pode reduzir à comunicação verbal de conteúdo doutrinário, sem referir-se a formas específicas de envolvimento humano no mundo". ${ }^{34}$ Para Padilla, o marxismo seria uma opção secular à esperança cristã de uma nova realidade e, embora não endossa em momento algum qualquer prognóstico marxista, defende que a humanidade sofre com aquilo que chama de "pecado estrutural": não só o homem, mas as estruturas sociais em si são injustas.

Isso não significa que o teólogo equatoriano propusesse uma ação revolucionária. Limita-se a provocar os participantes do Congresso ao falar da dimensão social do

31 PADILLA, René. A evangelização e o mundo (Comentário). In: GRAHAM, Billy et alli (Org.). A missão da igreja no mundo de hoje: as principais palestras do Congresso Internacional de Evangelização Mundial realizado em Lausanne, Suíça. São Paulo: ABU, 1984. p. 134.

32 PADILLA, 1984, p. 134.

33 PADILLA, 1984, p. 133.

34 PADILLA, 1984, p. 136-137. 
Evangelho, mas não há qualquer apelo ao engajamento com as lutas que se desenrolavam então. Tampouco, demonstra grande simpatia pela Teologia da Libertação. Em determinado momento, critica tanto o conversionismo como o "cristianismo secular", afirmando que com este, "sempre obcecado com a vida deste mundo, a única salvação possível é a que se atém aos limites da era atual. Trata-se de uma salvação essencialmente econômico-político-social”. Assim: “a Utopia absorve a Escatologia, e a esperança cristã confunde-se com a esperança mundana proclamada pelo Marxismo". Quanto ao outro extremo que propaga "o conceito de salvação como salvação futura da alma, no qual a presente vida só tem sentido como preparação para o 'amanhã'”, revela-se, na sua visão, um "meio de escapar à realidade presente". Para ele, a "compreensão equivocada do Evangelho é que tem feito levantar a crítica marxista contra a escatologia cristã, tachando-a de "ópio do povo". 35

Portanto, para Padilla a escatologia do "cristianismo secular" seria demasiadamente intramundana, ao passo que o conversionismo representaria um olhar alienante ou escapista da realidade. O que propõe é um olhar conjunto, que englobe a realidade espiritual e mundana. Todavia, em nenhum momento diz como o fazer. Provavelmente, o ambiente de Lausanne fosse deveras sensível para qualquer proposição mais concreta, que pudesse repercutir no campo de discussões políticas. Também é provável que os evangelicais latino-americanos não tivessem nenhum projeto claro a esse respeito.

Mas, possivelmente, o que gerou maior celeuma em sua preleção foi a crítica que o equatoriano fez àquilo que chamou de "Cristianismo Etnocêntrico" e, também, ao legalismo evangélico. Quanto a este último, chamou-o de "mundanismo" e, usando uma linguagem paulina, de "rudimentos fracos e pobres". ${ }^{36}$ O Cristianismo Etnocêntrico, por sua vez, era associado ao American way of life, conforme afirma:

Hoje, entretanto, há uma outra forma de "Cristianismo Etnocêntrico" dominando o cenário mundial: o estilo de vida americano (o American way of life) (...). O Evangelho hoje pregado na maioria dos países exibe marcas do "estilo americano de vida" (...) A imagem do cristão projetada por algumas formas de Cristianismo americano é a do "homem de negócios" bem sucedido, que encontrou a fórmula da felicidade; fórmula que ele deseja partilhar gratuitamente com outros. ${ }^{37}$

35 PADILLA, 1984, p. 149.

36 É possível inferir da resposta de Padilla aos comentários posteriores à preleção, que suas palavras não foram muito bem recebidas. O equatoriano afirma: "um dos meus críticos pergunta: ‘Por que considerar o legalismo como mundanismo? A Bíblia está cheia de mandamentos negativos'" (1984, p. 156). Parece que alguns dos presentes no Congresso vinham de uma tradição tão asceta e conservadora que nem ao menos a ideia abstrata de legalismo lhes parecia ter uma conotação negativa. PADILLA, 1984, p. 141.

37 PADILLA, 1984, p. 144. 
Essas colocações foram mal recebidas por alguns dos anfitriões de Lausanne. Padilla afirma, ao responder aos comentários feitos à sua preleção: "para um dos meus críticos, a descrição que faço desse tipo de cristianismo não passa de uma caricatura, impedindo a compreensão de muitas verdades pelas pessoas presentes a este Congresso". 38 Contudo, ao rebater as críticas, Padilla vai mais fundo na sua denúncia do Cristianismo Etnocêntrico e expõe uma realidade que, aparentemente, não fora explorada no Congresso, por ser de certa forma mais delicada: a segregação racial nas igrejas evangélicas. Quanto a este aspecto, o preletor indignava-se:

(...) como é possível ao Cristianismo de cultura americana integrar segregação racial e a segregação de classes em sua estratégia de evangelização mundial. A ideia aqui é a de que as pessoas gostam de estar juntas com as de sua própria raça ou classe, de modo que precisamos construir igrejas segregadas, as quais, sem dúvida alguma, crescerão mais rápido. Já nos disseram que o preconceito racial "pode ser compreendido e deveria transformar-se num recurso auxiliar da cristianização". Nenhuma operação exegética, por mais peso que tenha, jamais alinhará tal procedimento com a lição explícita do Novo Testamento relativa à unidade dos homens no Corpo de Cristo. ${ }^{39}$

É difícil saber se havia em Lausanne representantes de igrejas que praticavam segregação racial. O próprio Graham foi um opositor dessa prática discriminatória nos EUA. Mas, considerando a diversidade e o grande número de convidados para o Congresso, assim como a preocupação de Padilla em denunciar o etnocentrismo dos cristãos evangélicos, é possível que essa não fosse uma realidade tão distante.

Portanto, embora Padilla fosse teologicamente conservador - na esteira do avivalismo protestante no qual fora formado, enfatizando uma soteriologia cuja necessidade de conversão pessoal é central, criticando o universalismo teológico, a Teologia da Libertação e o marxismo - também era crítico do projeto de poder norteamericano, em que se propala o American way of life como uma virtude e um modelo de cristianismo a ser seguido, assim como do conversionismo pragmático da escola de Fuller, do legalismo evangélico e do segregacionismo. Neste sentido, representa uma voz dissonante num Congresso composto por brancos de classe média, representativa da realidade latino-americana, plural e desigual em vários sentidos.

Com Escobar ficam mais claras as implicações sociais da concepção latinoamericana de "integralidade da missão", embora ainda fossem tímidas. A evangelização apresentada em sua tese $\mathrm{e}^{40}$ ainda é, provavelmente, tributária do conversionismo

38 PADILHA, 1984, p. 158.

39 PADILHA, 1984, p. 159.

40 ESCOBAR, Samuel, A evangelização e a busca de liberdade, de justiça e de realização pelo homem (tese). In: GRAHAM, Billy et alli (Org.). A missão da igreja no mundo de hoje: as principais palestras do Congresso Internacional de Evangelização Mundial realizado em Lausanne, Suíça. São Paulo: ABU, 1984. p. 173-194. 
evangélico, uma tônica do Congresso que não se pode ignorar: a preocupação central e o motivo pelo qual foi convocado é a "evangelização mundial".

Portanto, por mais que alguns participantes tivessem maiores preocupações sociais, esse não era o melhor ambiente para tais discussões. Ainda assim, a preleção de Escobar é bem provocativa. Parece atribuir as dificuldades na evangelização ao descaso dos evangélicos do primeiro mundo com as questões da pobreza e desigualdade social no cenário global, iniciando sua fala de forma bem ilustrativa a este respeito, ao relacionar o desinteresse social evangélico com o projeto de poder das potências econômicas do Ocidente. Segundo ele:

Se colocarmos juntos o crescente desequilíbrio do desenvolvimento e afluência no mundo, as relações passadas entre as potências "cristãs" ocidentais e o empreendimento missionário no Terceiro Mundo, poderemos compreender por que suspeitam que a tarefa integral de evangelização em suas dimensões seja apenas um "complô imperialista", uma forma ocidental de manipulação das pessoas. ${ }^{41}$

Toda essa argumentação pode levar a crer que Escobar também nutrisse uma espécie de interesse pragmático pela ação social, uma vez que atribui o fracasso da evangelização à desigualdade social e à apatia evangélica quanto a tais questões. Contudo, adiante, o próprio teólogo peruano argumenta a esse respeito, que o "serviço cristão não é opcional", é antes uma missão de igual importância: "não devemos tentar justificar o serviço em favor do nosso semelhante afirmando que ele 'nos ajudará' em nossa tarefa evangelística". ${ }^{2} \mathrm{Ou}$ seja, no conceito de Escobar, ação social não é uma estratégia para a missão autêntica da igreja: a evangelização. Por sua vez, também não é missão de importância secundária, ou a ser exercida apenas no âmbito individual de atuação: a ação social é missão, tanto quanto a evangelização. Essa é uma das diferenças significativas no discurso latino-americano, na configuração do campo de disputas entre os grupos representados em Lausanne.

No entanto, mais uma vez, a despeito das diferenças concernentes ao conceito de missão, o que une os evangelicais do Primeiro e do Terceiro Mundos é a oposição ao ecumenismo e ao evangelho social. Escobar critica o American way of life, assim como critica o evangelho social, visto como um esforço do liberalismo "para tornar o Evangelho mais apetitoso ao espírito racionalista do século XIX e começo do século XX". ${ }^{43}$ Em sua preleção, ainda é mais ousado que Padilla ao criticar a associação que se faz entre cristianismo e Ocidente, conservadorismo social e capitalismo, apontando que, a "maior tentação hoje em dia na vida do cristão que deseja evangelizar ou ingressar no trabalho missionário é tomar

41 ESCOBAR, 1984, p. 175.

42 ESCOBAR, 1984, p. 179

43 ESCOBAR, 1984, p. 183-184. 
o Cristianismo como a religião oficial que explica, justifica e apóia o que as nações ocidentais fazem". ${ }^{4}$

Chega a ironizar em alguns momentos o anticomunismo exacerbado e o conservadorismo social dos evangélicos, valendo-se como instrumento retórico da comparação entre o evangelho e o conservadorismo político com as releituras da teologia liberal do século XIX, demonizada pelos evangélicos:

Se, como evangélicos, rejeitamos a adaptação liberal do Evangelho ao racionalismo do século XIX, devemos também rejeitar a adaptação do Evangelho ao conformismo e conservadorismo sociais da classe média deste poderoso Ocidente (...). O preço da obediência pode ser a morte, e os que gozam da chamada liberdade ocidental não devem pensar que a desobediência a César é um dever só quando César não é capitalista. ${ }^{45}$

Além disso, assim como Padilla, denuncia a indiferença frente aos regimes de sectarismo racial, argumentando que "o Evangelho é uma mensagem espiritual que nada tem a dizer sobre problemas sociais, e a tarefa da evangelização e do trabalho missionário é arrebatar almas das garras do inferno e da condenação". Assim, por exemplo, referindose à existência de grupos com tendências racistas, afirma: "não deveríamos nos preocupar com os seus preconceitos falando-lhes da igualdade perante Deus. Qualquer referência bíblica sobre raça pode ser interpretada de maneira que não perturbe a ordem jurídicosocial vigente" ${ }^{46}$

É interessante, ainda, notar as menções que Escobar faz aos evangélicos na América Latina. Tal observação ajuda na compreensão da identidade evangelical, ou seja, como os próprios evangelicais se veem. Primeiramente, o teólogo peruano faz menção ao que seria o passado dos evangélicos latino-americanos:

Na América Latina, por outro lado, a presença de missionários evangélicos em países como o México, Peru, Argentina, Guatemala e Equador foi saudada pelos paladinos da justiça e liberdade social. A razão disso é que a velha estrutura social, com sua organização feudalística, era abençoada pela Igreja Católica. De modo que a presença desses missionários, cuja pregação era um evangelho de libertação de uma religiosidade semipagã, produziu combatentes em prol da liberdade social; (...) em diversos países latino-americanos os evangélicos têm sido também defensores dos direitos da maioria indígena escravizada por séculos de dominação branca. ${ }^{47}$

4 ESCOBAR, 1974, p. 176.

4 ESCOBAR, 1984, p. 193.

46 ESCOBAR, 1984, p. 176.

47 ESCOBAR, 1984, p. 180. 
Em outro momento, Escobar menciona a realidade da igreja evangélica latinoamericana de sua época e a grande evasão da juventude engajada com as questões sociais e desencantada com a instituição religiosa:

Muitos jovens na América Latina, motivados pela (sic) Evangelho a amar o seu próximo e a ter preocupações com a justiça e a liberdade sociais, tornaram-se marxistas, com frequência, simplesmente porque suas igrejas não foram capazes de prover instrução bíblica sobre o discipulado cristão, ou porque eram cegas às exigências bíblicas e às oportunidades e aos desafios criados pelas novas situações sociais. ${ }^{48}$

Esta adesão da juventude evangélica à ideologia marxista é vista com preocupação por Escobar, revelando que, no momento aqui estudado, as disputas que configuravam o campo religioso não se davam apenas em torno de diferentes denominações cristãs, ou das tendências mais ou menos conservadoras dentro do próprio evangelicalismo, mas em relação a ideologias e projetos políticos alternativos em voga no continente, como os de inspiração marxista, denunciando a profunda interferência entre os campos político e religioso.

Por fim, concluindo o pensamento de Escobar, fica óbvio qual seu entendimento sobre o conceito de "missão integral", o qual deveria implicar que os cristãos do poderoso Ocidente, ou em posição de influência, deveriam abandonar a indiferença e buscar padrões mais justos de consumo, comércio e política, derivando uma "postura crítica à corrupção na corrida armamentista e nas manobras quase onipotentes de espionagem internacional" ${ }^{49}$

Ainda assim, embora avance um pouco em relação às colocações de Padilla, não há um posicionamento político certo e talvez o único engajamento com uma luta específica seja quanto ao regime de segregação racial. Ambos os teólogos compartilham de uma teologia conservadora e de uma rejeição intransigente ao ecumenismo, ao evangelho social e à teologia liberal do século XIX, embora se posicionem criticamente em relação aos padrões de consumo e ao pragmatismo dos evangélicos anglo-saxões, defendendo uma práxis mais engajada com as questões sociais.

\section{Considerações finais}

Com base na problemática analisada, foi possível qualificar os referenciais que balizaram a construção da identidade evangelical, a partir de uma abordagem histórica do movimento e de suas práticas discursivas. Assim, o protestantismo de missão, num primeiro momento, forma sua identidade em oposição ao catolicismo; num segundo

49 ESCOBAR, 1984, p. 192. 
momento, o protestantismo se identifica com as lutas sociais do continente: o ecumenismo que se desenvolve em âmbito global, principalmente a partir de 1948 com a criação do CMI. O evangelicalismo, por sua vez, desenvolve-se em franca oposição ao ecumenismo, mas, num segundo momento, o evangelicalismo latino-americano desenvolve uma identidade distinta do Evangelical Movement anglo-saxão.

O Congresso de Lausanne constitui momento privilegiado na maturação desta identidade. Embora pouco plural - uma vez que nasce como uma oposição ao ecumenismo e, portanto, tem barreiras dogmáticas mais rígidas -, há uma distinção bem marcada entre o discurso dos anglo-saxões - os "donos da festa" - e os representantes do Terceiro Mundo - especificamente, os latino-americanos René Padilla e Samuel Escobar -, como ficou exposto na análise das preleções.

O primeiro grupo tem uma preocupação bem definida com a evangelização enquanto comunicação verbal do evangelho, principalmente dos continentes ainda "não alcançados"; revela um pragmatismo quanto aos métodos de evangelização; compartilha de uma escatologia apocalipsista. Os latino-americanos, por sua vez, rejeitam o projeto de poder dos norte-americanos; são críticos da prática de segregação social e do padrão e consumo das igrejas nos países desenvolvidos, propondo uma missiologia engajada com as questões políticas e sociais do momento. Ainda assim, ambos os grupos são teologicamente conservadores, anti-ecumênicos e exclusivistas.

\section{Referências}

BINGEMER, Maria Clara L. O mistério e o mundo: paixão por Deus em tempos de descrença. Rio de Janeiro: Rocco, 2013.

BONINO, José Míguez. Rostos do protestantismo latino-americano. São Leopoldo: Sinodal, 2003.

BOURDIEU, Pierre. A economia das trocas simbólicas. São Paulo: Perspectivas, 2005.

ESCOBAR, Samuel, A evangelização e a busca de liberdade, de justiça e de realização pelo homem (tese). In: GRAHAM, Billy et alli (Org.). A missão da igreja no mundo de hoje: as principais palestras do Congresso Internacional de Evangelização Mundial realizado em Lausanne, Suíça. São Paulo: ABU, 1984.

GRAHAM, B. Por que Lausanne. In: GRAHAM, Billy et alli (Org.). A missão da igreja no mundo de hoje: as principais palestras do Congresso Internacional de Evangelização Mundial realizado em Lausanne, Suíça. São Paulo: ABU, 1984.

GRAHAM, Billy et alli (Org.). A missão da igreja no mundo de hoje: as principais palestras do Congresso Internacional de Evangelização Mundial realizado em Lausanne, Suíça. São Paulo: ABU, 1984. 
HERVIEU-LÉGER, Daniéle. El peregrino y el convertido: la religión en movimiento. México: Ediciones del Helénico, 2004.

LONGUINI NETO, Luiz. O novo rosto da missão. Viçosa: Ultimato, 2002.

MARSDEN, George. Understanding Fundamentalism and Evangelicalism. Grand Rapids: Wm. B. Eerdmans Publishing Co.,1991.

MENDONÇA, Antonio G. O protestantismo no Brasil e suas encruzilhadas. Revista USP, São Paulo, n. 67, set./nov. 2005.

. República e pluralidade religiosa no Brasil. Revista USP, São Paulo, n. 59, set./nov. 2003.

ORLANDI, Eni P. Análise de Discurso. 8. ed. Campinas: Fontes, 2009.

PADILLA, René. A evangelização e o mundo (Comentário). In: GRAHAM, Billy et alli (Org.). A missão da igreja no mundo de hoje: as principais palestras do Congresso Internacional de Evangelização Mundial realizado em Lausanne, Suíça. São Paulo: ABU, 1984.

PANASIEWICZ, Roberlei. Secularização: o fim da religião?. In: ANDRADE, Paulo F. C. de; BINGEMER, Maria C. (Orgs.). Secularização: novos desafios. Rio de Janeiro: PUC-Rio, 2012.

RODRIGUES, Ricardo Gondim. Sem perder a alma. Rio de Janeiro: MK, 2008.

STOTT, J. Bases bíblicas da evangelização. In: GRAHAM, Billy et alli (Org.). A missão da igreja no mundo de hoje: as principais palestras do Congresso Internacional de Evangelização Mundial realizado em Lausanne, Suíça. São Paulo: ABU, 1984. 